\title{
PERANCANGAN INFOGRAFIS ASI EKSKLUSIF SEBAGAI UPAYA PENINGKATAN KESADARAN MASYARAKAT PADA GIZI BAYI
}

\author{
Dhika Yuan Yurisma', Muh.Bahruddin ${ }^{2}$, Sigit P. ${ }^{3}$ \\ 1,2,3 Desain Komunikasi Visual, Fakultas Teknologi Informasi, \\ Institut Bisnis dan Informatika Stikom Surabaya \\ dhika@stikom.edu', bahruddin@stikom.edu², sigit@stikom.edu ${ }^{3}$
}

\begin{abstract}
Abstrak
Media berbasis infografis masih jarang ditemui di dinas-dinas kesehatan, Pusat Kesehatan Masyarakat (Puskesmas), posyandu, BKIA, bidan, rumah sakit bersalin, dan lain sebagainya. Di tempat-tempat tersebut hanya menampilkan gambar ibu-ibu menyusui. Dari tahun ke tahun, gambar tersebut tidak banyak perubahan, kecuali hanya menginformasikan bahwa ASI Eksklusif adalah asupan utama bayi yang sangat penting. Penelitian ini bertujuan untuk merancang infografis yang akan diimplementasikan melalui media poster yang bertujuan memberikan informasi tentang pentingnya ASI Eksklusif. Peneliti berharap bahwa perancangan infografis ini mampu memberikan dampak signifikan bagi masyarakat, khususnya orangtua untuk meningkatkan kesadaran terhadap pentingnya gizi bayi. Infografis dimaksudkan untuk mengomunikasikan informasi dengan cara yang jelas melalui grafis (gambar), mudah dipahami masyarakat awam, dan menjadi media komunikasi yang efektif. Dengan menggunakan metode wawancara mendalam kepada tenaga kesehatan atau media, ibu rumah tangga, akademisi, maka hasil yang telah dicapai dalam penelitian ini adalah desain infografis yang dituangkan dalam sebuah poster menjadi media yang penting bagi masyarakat untuk memperoleh informasi tentang pentingnya ASI. Minimnya publikasi tentang ASI menjadikan poster desain infografis menjadi sangat dibutuhkan masyarakat. Untuk memenuhi kebutuhan itu, peneliti menggunakan gaya desain flat design dalam merancang desain infografis. Gaya ini mudah diaplikasikan dan relevan ditujukan sesuai target dan segmentasi.
\end{abstract}

Kata Kunci: ASI Eksklusif, Infografis, Flat design

\begin{abstract}
Media-based infographic is still rare in the health services, Community Health Center (Puskesmas), Posyandu, maternity, midwife, maternity hospitals, and so forth. In these places just to show pictures of mothers breastfeeding. From year to year, the picture is not much change, except to inform you that exclusive breastfeeding is the main intake baby is very important. This research aims to design an infographic that will be implemented via the posters aimed at providing information about the importance of exclusive breastfeeding. Researchers hope that this infographic design capable of providing a significant impact to the community, especially parents to raise awareness of the importance of infant nutrition. Infographics are intended to communicate information in a clear way through the graphics (pictures), easy to understand ordinary people, and become effective communication media. By using depth interviews with health workers or media, housewives, academics, the results achieved in this research is the design infographics set forth in a poster becomes important medium for people to obtain information about the importance of breastfeeding. The lack of publicity about breastfeeding makes the poster design infographics become indispensable community. To meet that need, the researchers use a flat design style design in designing infographics design. This style is easy to apply and is intended as targeted and relevant segmentation.
\end{abstract}

Keywords: ASI Eksklusif, Infografis, Flat design 


\section{PENDAHULUAN}

Saat ini ada sejumlah persoalan terkait makanan dan kesehatan bayi berusia di bawah lima tahun (balita) cukup memprihatinkan. Kasus susu formula yang diduga mengandung bakteri enterobacter sakazakii dan sejumlah kasus balita yang mengalami alergi terhadap protein susu sapi (susu formula) memperlihatkan betapa minimnya komunikasi kesehatan tentang Air Susu Ibu (ASI) eksklusif yang dilakukan pemerintah, khususnya dalam penggunaan media sebagai sarana komunikasi. Sementara di sisi lain iklan susu formula semakin masif membanjiri media. Penelitian ini hendak diarahkan untuk merancang infografis ASI eksklusif sebagai upaya meningkatkan kesadaran masyarakat pada gizi bayi.

Departemen Kesehatan Republik Indonesia mendefenisikan Air Susu Ibu (ASI) eksklusif sebagai kegiatan yang hanya menyusui bayi dan tidak memberi makanan atau minuman lain, termasuk air putih, kecuali obat-obatan dan vitamin atau mineral tetes; ASI perah juga diperbolehkan, yang dilakukan sampai bayi berumur 6 bulan (depkes.go.id diakses 20 Maret 2016). Data Riset Kesehatan Dasar (Riskesdas) tahun 2013 menunjukkan bahwa pemberian ASI di Indonesia masih memprihatinkan, persentase bayi yang menyusu eksklusif sampai dengan 6 bulan 54,3 persen secara nasional dari total jumlah bayi 1.348.532. sedangkan yang tidak ASI eksklusif sebesar 1.134.952. Artinya masih banyak bayi dianggap memiliki gizi yang kurang memadai. Hal ini disebabkan kesadaran masyarakat dalam mendorong peningkatan pemberian ASI masih relatif rendah. Padahal kandungan ASI kaya akan karotenoid dan selenium, sehingga ASI berperan dalam sistem pertahanan tubuh bayi untuk mencegah berbagai penyakit. Setiap tetes ASI juga mengandung mineral dan enzim untuk pencegahan penyakit dan antibodi yang lebih efektif dibandingkan dengan kandungan yang terdapat dalam susu formula (depkes.go.id diakses 20 Maret 2016).

Permasalahannya, media komunikasi untuk menyampaikan informasi tentang pentingnya ASI sangat minim, sehingga masyarakat kurang memiliki hak memperoleh informasi tentang pentingnya ASI. Meski pernah ditayangkan Iklan Layanan Masyarakat (ILM) di televisi tentang ASI, namun iklan tersebut bukan murni kampanye dari pemerintah, melainkan kepedulian Asosiasi Ibu Menyusui Indonesia (AIMI). Hal ini tidak sebanding dengan banyaknya iklan susu formula dari berbagai jenis perusahaan. Kenyataan ini dapat membentuk pemikiran masyarakat bahwa susu formula adalah makanan bayi yang sangat penting.

Berangkat dari persoalan tersebut, pemerintah perlu merumuskan komunikasi guna memenuhi hak masyarakat, khususnya media komunikasi yang tepat untuk menyampaikan sebuah informasi kepada masyarakat. Media menjadi sarana komunikasi efektif dalam penyampaian pesan. Media memiliki kekuatan untuk memengaruhi khalayak. Media juga memiliki jangkauan yang luas dalam menyebarkan berbagai pesan. Kelebihan inilah yang tidak dimiliki oleh saluran komunikasi lain.

Media berbasis infografis masih jarang ditemui di dinas-dinas kesehatan, puskesmas, posyandu, BKIA, bidan, rumah sakit bersalin, dan lain sebagainya. Di tempat-tempat 
tersebut hanya menampilkan gambar ibu-ibu menyusui. Dari tahun ke tahun, gambar tersebut tidak banyak perubahan, kecuali hanya menginformasikan bahwa ASI Eksklusif adalah asupan utama bayi yang sangat penting. Dalam penelitian ini, infografis akan diimplementasikan sebagai media yang akan memberikan informasi tentang akibat-akibat bayi yang tidak menggunakan ASI Eksklusif sehingga diharapkan mampu memberikan dampak signifikan bagi masyarakat, khususnya orangtua untuk meningkatkan kesadaran terhadap pentingnya gizi bayi. Dalam hal ini infografis dimaksudkan untuk mengomunikasikan informasi dengan cara yang lebih jelas.

\section{METODE PENELITIAN}

Tipe penelitian ini bersifat kualitatif. Hal ini karena peneliti ingin mendapatkan informasi secara mendalam tentang pentingnya ASI. Informan dipilih secara purposif yaitu ibu menyusui (atau pernah menyusui), serta pakar kesehatan masyarakat dan medis (seperti dosen Kesehatan Masyarakat, bidan, dan lain sebagainya). Hasil wawancara dianalisis dan diarahkan ke sebuah perancangan infografis tentang ASI. Pengumpulan data diambil dari hasil wawancara dengan informan. Peneliti mewawancarai tiga informan ibu menyusui dengan kategori latar belakang pendidikan, ekonomi, dan sosial yang berbeda. Wawancara difokuskan pada pengetahuan tentang ASI Eksklusif, dan manfaat ASI Eksklusif. Untuk mendukung penelitian, peneliti juga melengkapi dengan informasi tentang minimnya iklan ASI eksklusif di lingkungan dinas kesehatan. Selain itu, peneliti juga melakukan observasi untuk menemukan data secara mendalam tentang latar belakang permasalahan sehingga membentuk pola pikir dan perilaku informan. Penelitian ini dilengkapi dengan data-data pendukung yang bersifat kepustakaan untuk menguatkan data-data yang dihasilkan di lapangan.

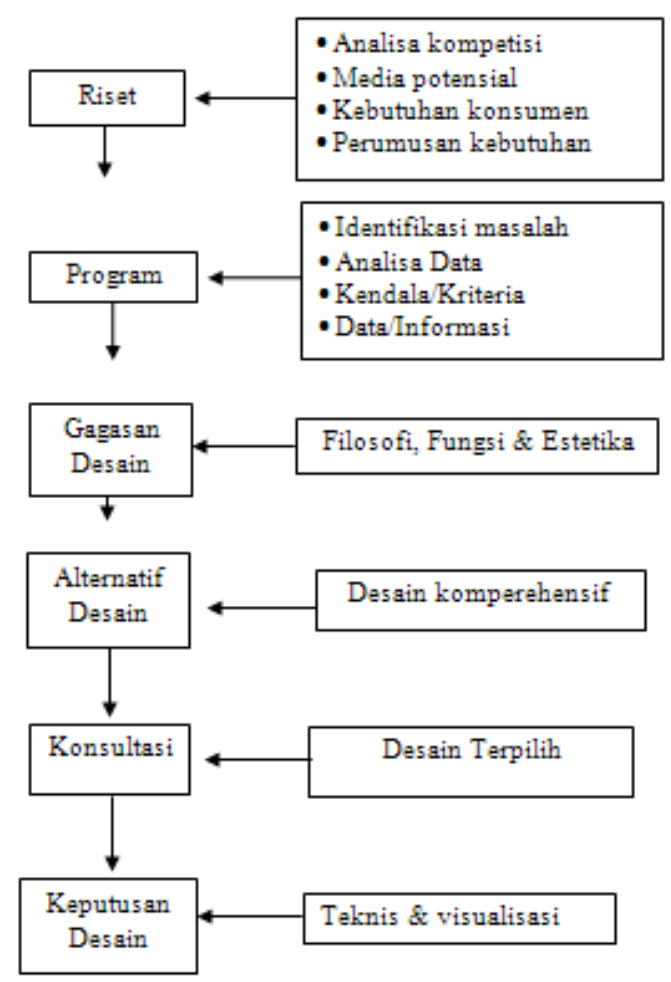

Gambar 1. Prosedur Perancangan [Sumber: Penulis] 
Teknik analisis data dilakukan dengan cara memetakan hasil wawancara sesuai dengan latar belakang dan kondisi sosial informan. Dari hasil tersebut diharapkan akan melahirkan konsep perancangan infografis yang sesuai dengan segmentasi, target, dan positioning. Hasil ini akan mendukung efektivitas infografis sebagai sarana untuk mengomunikasikan pesan kesehatan kepada masyarakat sehingga diharapkan mampu meningkatkan kesadaran tentang pentingnya gizi pada bayi.

\section{HASIL DAN PEMBAHASAN}

Berdasarkan metode penelitian yang telah dijelaskan di bab sebelumnya, maka hasil yang dicapai dalam penelitian ini menghasilkan data-data berupa data observasi dan wawancara mendalam dengan beberapa informan antara lain dari ibu menyusui, bidan, akademisi, dan pakar.

Dari hasil penelitian Achmad Syafiq yang berjudul ASI Eksklusif dan Persepsi Ketidakcukupan ASI disebutkan bahwa persentase persepsi ketidakcukupan air susu ibu (PKA) adalah keadaan ibu merasa ASI-nya tidak cukup untuk memenuhi kebutuhan bayinya ditemukan cukup tinggi. Variabel pengetahuan asupan energi, dan IMD, secara signifikan berhubungan dengan PKA setelah dikontrol variabel status gizi, paritas, rawat gabung, perlekatan menyusui, dukungan keluarga, dan dukungan tenaga kesehatan. Ibu yang pengetahuan ASI-nya kurang berisiko 12 kali lebih besar mengalami PKA dibandingkan dengan ibu yang pengetahuannya baik. Ibu yang asupan energinya kurang berisiko hampir empat kali lebih besar mengalami PKA dibandingkan dengan ibu yang asupan energinya cukup. Sedangkan ibu yang tidak melaksanakan IMD berisiko tiga kali lebih besar mengalami PKA dibandingkan dengan ibu yang melaksanakan IMD. Pengetahuan merupakan faktor yang paling dominan berhubungan dengan PKA.

Berdasarkan kajian yang dilakukan oleh Sandra Fikawati, Ahmad Syafiq yang diterbitkan dalam jurnal Makara Universitas Indonesia. Kajian tersebut menemukan bahwa pemberian ASI eksklusif di Indonesia masih rendah dan fasilitasi IMD belum optimal. Analisis kebijakan menunjukkan bahwa kebijakan mengenai ASI eksklusif belum lengkap dan belum komprehensif. Juga ditemukan bahwa IMD belum secara ekskplisit dimasukkan dalam kebijakan. Analisis kerangka kerja koalisi advokasi mengonfirmasi lemahnya aspek sistem eksternal dan subsistem kebijakan dalam penyusunan kebijakan ASI eksklusif. Peraturan-peraturan yang dibahas dalam analisis ini masih terlepas dari konteksnya baik konteks individu, keluarga, masyarakat, maupun institusi. Dari segi proses, penyusunan kebijakan terlihat kurang transparan, lambat dan kurang partisipatoris. Belum ada pemetaan pemeran (aktor) yang jelas terutama pengaturan kewenangan dan tanggung jawab yang bersifat lintas sektoral dan lintas level. Analisis kerangka kerja koalisi advokasi mengonfirmasi temuantemuan hasil analisis dengan metode sebelumnya dengan tekanan pada lemahnya aspek sistem eksternal dan subsistem kebijakan dalam.

Penelitian ini mewawancarai sejumlah informan, antara lain Yulia Rachmi, seorang ibu menyusui. Yulia Rachmi tidak mendapatkan informasi yang cukup dari puskesmas atau 
klinik kesehatan tentang ASI eksklusif saat melahirkan. Selama ini ibu menyusui lebih mendapatkan informasi tersebut melalui internet dan nasehat-nasehat orang tua. Yulia mengaku harus mengkonsumsi jamu tradisional untuk memperlancar ASI-nya. Informasi mengenai perawatan terhadap payudara bahkan belum diketahuinya. Minimnya informasi tentang pentingnya ASI, perawatannya, serta kesehatan ibu menyusui yang terdapat pada puskesmas membuat ibu-ibu menyusui seperti Yulia ini justru lebih tertarik dengan untuk menggunakan susu formula yang dianggap lebih praktis.

Sedangkan Setyaning Rahayu, seorang bidan, menjelaskan bahwa produsen-produsen susu formula selalu datang kepuskesmas dan tempat praktiknya. Mereka selalu menawarkan imbalan yang menggiurkan bila bidan mempromosikan pasiennya untuk menggunakan susu tersebut. Mengenai informasi tentang ASI eksklusif, dia menuturkan bahwa poster-poster tersebut sudah lama tidak dikirim oleh dinas kesehatan setempat. Terkait dengan betapa pentingnya ASI eksklusif bagi bayi, Setyaning menjelaskan bahwa ASI dibutuhkan bayi sejak 1 jam kelahiran pertamanya. Hal ini dikarenakan dapat mendorong ikatan antara ibu dan bayi. Di wilayah tempat praktiknya, masyarakat setempat masih menggunakan perawatan atas dasar tradisi orang-orang terdahulunya, yaitu menggunakan jamu, padahal jamu tidak menjamin akan melancarkan dan menyehatkan ASI malah dalam beberapa kasus jamu dapat menghambat ASI yang diproduksi.

Florensa, seorang dosen pendidikan keperawatan dan mahasiswa S3 IImu Keperawatan Universitas Indonesia, mengatakan bahwa sosialisasi ke Puskesmas dan rumah sakit dari tenaga kesehatan sebenarnya pelayanan cukup baik, khususnya di ruang nifas (ruang tempat ibu pasca melahirkan). Selain teori, juga cara menyusui. Selama masa kehamilan, bumil juga sudah diberi pendidikan kesehatan akan pentingnya ASI dan cara perawatan payudara agar secara fisik si ibu siap untuk menyusui. Menurutnya, jika ada perawat atau dokter (tenaga medis) yang mengatakan bahwa orang yang selesai operasi caesar akan kesulitan menyusui, hal ini harus diluruskan. Seorang ibu atau ayah mempunyai hak untuk menolak jika diminta tenaga medis untuk mengganti dengan susu formula.

Hal ini sejalan dengan yang dikatakan oleh Lestari Oktavia, seorang dosen prodi IImu Gizi Komunitas, Fakultas Kedokteran Universitas Gunadarma Jakarta. Pesan dari pemerintah sebenarnya jelas. Namun coverage ASI eksklusif terus menurun. Di rumah sakit besar, sebenarnya pemberian susu formula harus sepengetahuan orang tua. Usaha pemerintah sebenarnya cukup baik. Namun, sejauh ini belum diketahui sejauh mana distorsi pesan sehingga pesan tersebut tidak sampai secara efektif di masyarakat. Apakah ada di petugas kesehatan atau orangtua sendiri yang memutuskan untuk tidak memberi ASI Eksklusif. Menurutnya, ASI itu otomatis keluar meskipun dengan operasi caesar. Jika ada rumah sakit (dokter atau perawat) yang menyuruh pasien untuk mengonsumsi susu formula, maka pasien berhak menolak. Jika dipaksa, pasien berhak menuntut. Karena hal ini akan mengakibatkan si anak tidak menerima colostrum. 
Colostrum adalah cairan susu yang dihasilkan oleh seorang ibu ketika melahirkan. Cairan ini bermanfaat untuk meningkatkan antibodi, faktor peningkat kekebalan tubuh, dan sangat penting untuk menjaga kesehatan serta vitalitas. Unsur imunitas yang terkandung di dalam kolostrum dikenal sebagai PRP (Proline Rich Polypeptide) yaitu zat yang mampu membangun kembali jaringan yang sehat, dan aktif untuk meningkatkan kualitas imun. Colostrum merupakan sebuah jenis cairan yang sangat mudah untuk dicerna oleh bayi karena memberikan beberapa enzim penting. Colostrum selain berfungsi di saat bayi baru lahir, juga memiliki tingkat manfaat hingga ke masa depan (http://susu-kolostrum.org/colostrum-adalah-mengenal-artikolostrum/ diakses 28 November 2016).

Florensa juga mengatakan bahwa dengan isapan bayi kepada putting payudara seorang ibu, maka merangsang kontraksi uterus yang dapat mencegah perdarahan pada ibu pasca melahirkan. Jika ada ibu yang habis operasi caesar kondisinya lemah, tetap harus dimotivasi untuk bisa menyusui dengan ASI. Ini tugas tenaga medis dan seorang suami. Jika, ASI keluarnya sedikit, itu wajar. Bila dirangsang dengan isapan bayi, akan membantu produksi ASI lebih baik. Maka tugas pelayanan di tingkat primer (Puskesmas), sosialisasi harus diberikan bukan hanya kepada ibu, tapi support sistem juga sangat penting mengetahui manfaat ASI yang besar, baik bagi bayi maupun si ibu sendiri. Support juga kepada harus datang dari suami, keluarga, bahkan masyarakat lingkungan sekitar.

Capaian ASI eksklusif di Indonesia belum mencapai angka yang diharapkan yaitu sebesar 80\%. Berdasarkan laporan SDKI tahun 2012 pencapaian ASI eksklusif adalah 42\%. Sedangkan, berdasarkan laporan dari Dinas Kesehatan di setiap provinsi di Indonesia pada tahun 2013, cakupan pemberian ASI 0-6 bulan hanyalah 54,3\% (Pusdatin, 2015). Salah satu faktor yang mempengaruhi rendahnya pemberian ASI Eksklusif di Indonesia adalah pesan yang disampaikan melalu media-media yang menyampaikan pesan tidak sampai secara efektif ke masyarakat. Faktor lain adalah adanya kerjasama pihak rumah sakit atau tmpat-tempat kesehatan yang bekerja sama dengan produsen susu formula sehingga pasien akan lebih memilih menggunakan susu formula.

Dari hasil wawancara tersebut dapat diketahui bahwa pentingnya ASI eksklusif yang memiliki manfaat sangat komplit seperti anti alergi, pembentukan sistem imun, multi vitamin, dan semua yang dibutuhkan. Lestari Oktavia menyarankan bahwa pemberian susu formula mestinya harus diresepkan oleh dokter sehingga jika tidak dapat resep, otomatis pasien wajib memberikan ASI eksklusif. Susu formula tidak boleh sembarangan dijual pada bayi berusia 0-6 bulan harus menggunakan resep. Selama masa kehamilan, ibu hamil seharusnya diberi pendidikan kesehatan akan pentingnya ASI dan cara perawatan payudara agar secara fisik ibu siap untuk menyusui.

Berdasarkan hasil pengumpulan data yang telah dilakukan diperoleh berbagai informasi mengenai ASI eksekutif yang akan disajikan dalam sebuah infografis. Dari data yang telah diperoleh akan direduksi dan dipilih data mana yang akan disajikan 
dalam infografis. Dari data tersebut maka informasi mengenai ASI eksklusif yang akan disajikan dalam bentuk infografis adalah Inisiasi Menyusu Dini (IMD), manfaat ASI Eksklusif, cara merawat payudara pada ibu menyusui, support dari tenaga media dan orang terdekat, serta cara melancarkan ASI.

Dalam merancang sebuah desain informasi diperlukannya strategi penyusun Segmentasi, Targeting, dan Potitioning agar media dan pesan dapat tersalurkan dengan baik. Berikkut adalah strategi STP yang telah dibuat.

\section{Segmentasi dan Targeting:}

a. Demografis

SES: $B, C, D$

Umur: $22-30$

Ibu muda, hidup di Indonesia

b. Psikografis

Mereka hidup di wilayah urban dan pada umumnya baru memiliki anak, mereka mempunyai kepedulian terhadap informasi-informasi baru, karenanya mereka menjadi antusias pada perkembangan dunia, melek teknologi. Pada fase ini yang terpenting bagi mereka adalah kebahagian keluarga, terutama segala sesuatu yang terbaik buat anaknya bukan yang lain. Kesibukan mereka beraneka ragam sehingga terkadanag mereka melupakan hal-hal penting lain karena dianggap sepele.

\section{Tone and Manner}

Inspiring, persuasif, faktual.

\section{Desire Response}

Edukasi mengenai ASI Eksklusif sangat penting, karena akan menentukan gizi bayi dan perkembangan bayi kedepannya.

\section{Perancangan Desain Infografis}

Perancangan desain infografis yang dimulai dari perancangan sketsa, alternatif hingga final desain. Perancangan infografis ini menggunakan gaya desain flat desain yang memberikan kesan simpel, sehingga mudah dimengerti oleh target sasaran infografis ini yaitu para ibu muda. Berdasarkan dari hasil creative brief yang telah disusun maka dihasilkan desain poster untuk Inisiasi Menyusu Dini (IMD), manfaat ASI Eksklusif, cara merawat payudara pada ibu menyusui, serta tips untuk melancarkan ASI. 


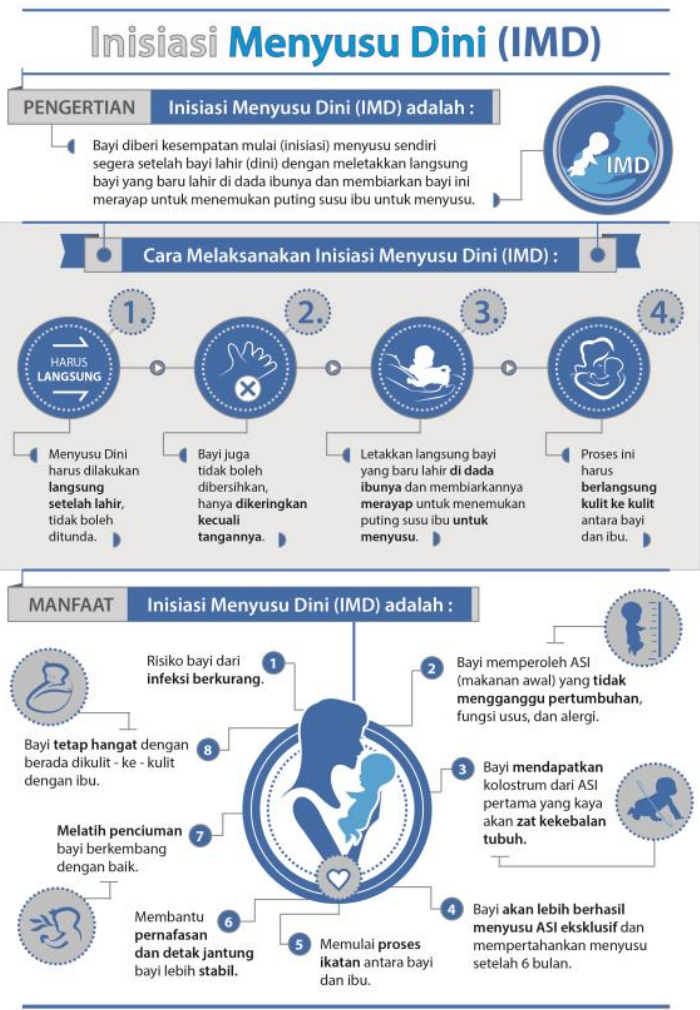

Gambar 2. Desain Poster Inisiasi Menyusu Dini [Sumber: Penulis]

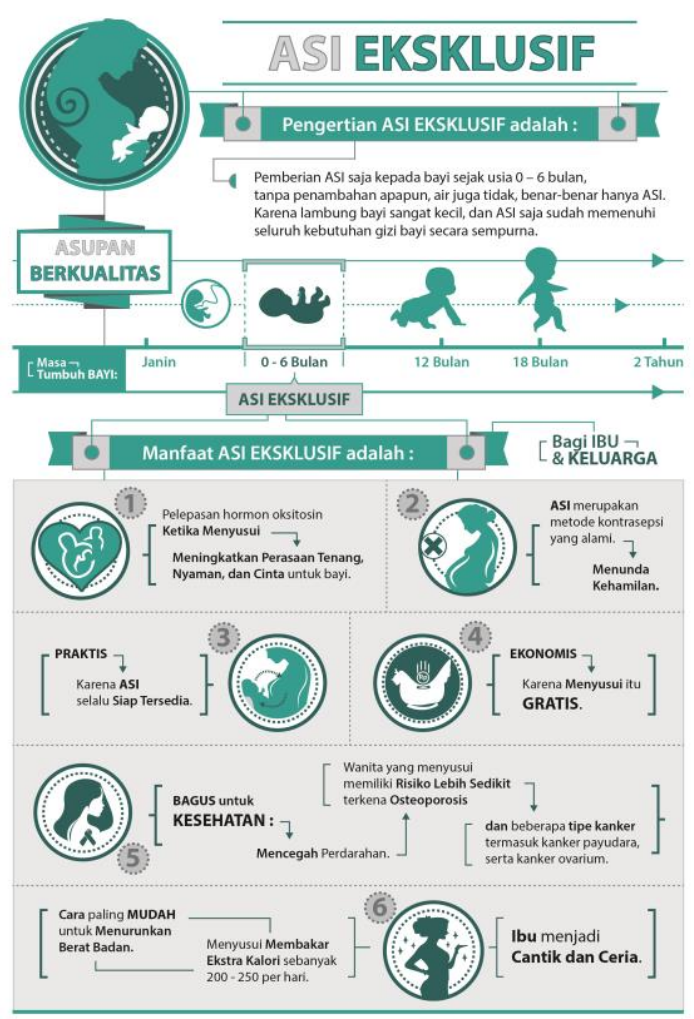

Gambar 3. Desain Poster ASI eksklusif

[Sumber: Penulis] 


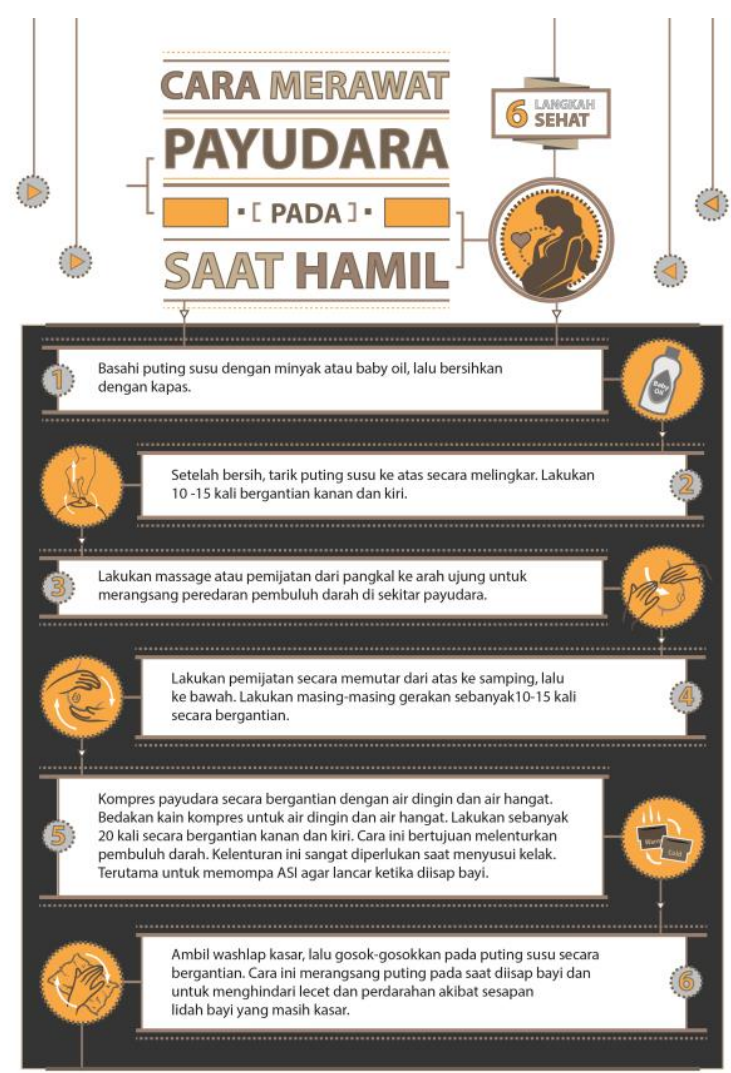

Gambar 4 Desain Poster Cara Merawat Payudara [Sumber: Penulis]

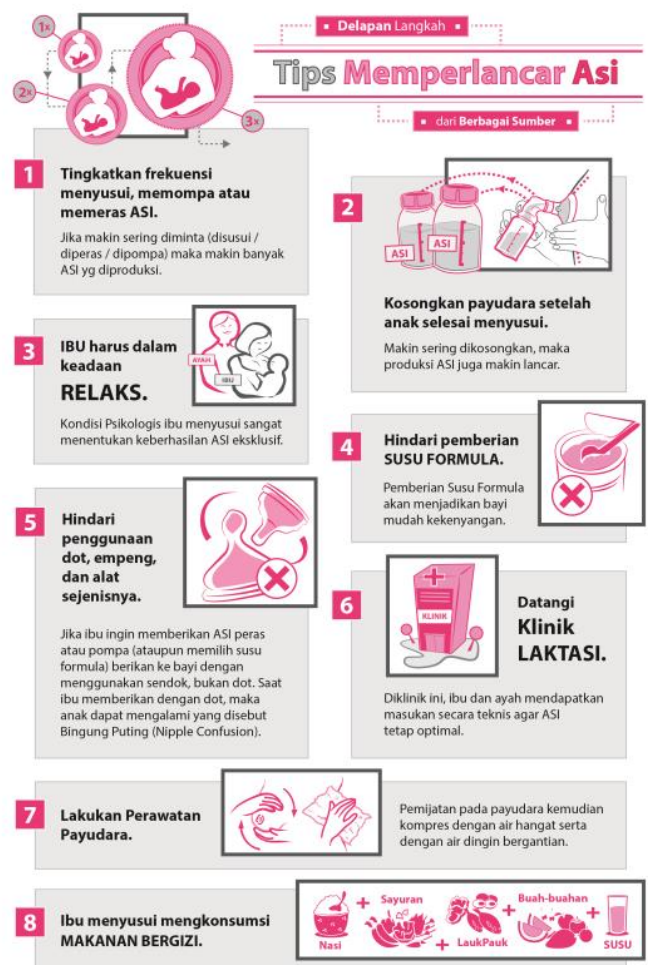

Gambar 5. Desain Poster Tips Memperlancar ASI [Sumber: Penulis] 


\section{KESIMPULAN}

Dari data dan hasil yang telah dibahas sebelumnya, maka penelitian ini dapat disimpulkan bahwa ASI Eksklusif merupakan asupan makanan utama dan paling penting bagi bayi berusia 0-6 tahun, tugas pelayanan dimulai dari tingkat primer (Puskesmas), rumah sakit, posyandu, dan tempat-tempat kesehatan. Sosialisasi harus diberikan bukan hanya kepada ibu, tapi support sistem juga sangat penting mengetahui manfaat ASI yang besar, baik bagi bayi maupun si ibu sendiri. Support juga kepada harus datang dari suami, keluarga, bahkan masyarakat lingkungan sekitarnya, perancangan desain infogragis berdasarkan data informasi mengenai ASI eksklusif yaitu Inisiasi Menyusu Dini (IMD), manfaat ASI Eksklusif, cara merawat payudara pada ibu menyusui, support dari tenaga media dan orang terdekat, serta cara melancarkan ASI.

\section{DAFTAR PUSTAKA}

Badan Pusat Statistik, BKKBN, Departemen Kesehatan. 2003. Survei Demografi dan Kesehatan Indonesia 2002-2003. Jakarta: Badan Pusat Statistik.

Badan Pusat Statistik, BKKBN, Departemen Kesehatan. 2007. Survei Demografi dan Kesehatan Indonesia 2006-2007. Jakarta: Badan Pusat Statistik.

Fikawati S, Syafiq A. 2009. Praktik pemberian ASI eksklusif, penyebab-penyebab keberhasilan dan kegagalannya. Jurnal Kesmas Nasional 2009; 4(3):120-131.

Syafiq A, Fikawati S. 2007. Mercy Corps Healthy Start Baseline Survey North Jakarta, Indonesia, Final Report. Depok: Center For Health Research University of Indonesia.

World Health Organization. 2002. The Optimal Duration of Exclusive Breastfeeding, Report of an Expert Consultation. Geneva, Switzerland: World Health Organization.

http://www.depkes.go.id/resources/download/pusdatin/infodatin/infodatin-asi.pdf (diakses 20 Maret 2016)

https://www.maxmanroe.com/mengenal-pengertian-infografis-dan-jenisnya.html (diakses 20 Maret 2016)

(http://susu-kolostrum.org/colostrum-adalah-mengenal-arti kolostrum/(diakses28November2016) 